\title{
INTRAPLATE SEISMICITY AND ZONATION
}

\author{
B A Bolt ${ }^{1}$
}

This paper was presented as one of the keynote addresses at the Pacific Conference on Earthquake Engineering, PCEE 95, Melbourne, November 1995.

\begin{abstract}
SUMMARY
Significant intraplate earthquakes have been observed under deep oceans and in all continents except Greenland. They present special problems of seismic risk estimation compared to the more frequent interplate earthquakes. Their location in space and time is more uncertain because of the low seismicity rate, scattered locations, and lack of surface seismogenic fault evidence. Nevertheless, recent geological and seismological work in several stable continents, particularly western North America and Australia, has improved the assessment of seismic hazard maps and risk zonation in such regions. Estimation of robust synthetic ground motion spectra and time histories, however, remains relatively uncertain. Strong motion instrumentation at Continental Reference Stations (CRS) is recommended.
\end{abstract}

\section{TECTONICS AND EARTHQUAKE OCCURRENCE}

The worldwide network of sensitive seismographs that has operated this century has now produced a reliable map of the distribution of the great majority of significant earthquakes around the Earth (see Figure 1). An explanation for the uneven geographical pattern is given by the theory of plate tectonics. First, most earthquakes occur in often extensive marginal zones along the edges of the interacting tectonic plates (interplate earthquakes), but a few, including some of large magnitude (such as the 1811 and 1812 New Madrid earthquakes in North America) occur within a plate (intraplate earthquakes). In some seismically active areas, such as along the Pacific margins of South America, Alaska, Japan (Benioff zones), and the Mediterranean margin of Europe, the convergence of the plates results in crustal rocks plunging down (subducting) into the Earth. These convergent plate boundaries contribute more than $90 \%$ of the Earth's release of seismic energy for shallow earthquakes, as well as most of the energy for intermediate and deep-focus earthquakes (down to $680 \mathrm{~km}$ depth). Most of Earth's largest earthquakes, such as the 1960 and 1985 Chile earthquakes, the 1964 Alaskan earthquake, and the 1985 Mexico earthquake, originate in subduction zones. A high rate of seismicity also occurs along the mid-oceanic ridges where the tectonic plates are created by volcanic processes along undersea faults. These diverging plate margins involve both dip-slip faulting (normal faults) and horizontal slip (transform faults). A much studied example of the latter is the San Andreas fault system, which connects the ocean ridges in the Gulf of California with the Gorda ridge under the Pacific Ocean off Oregon. Plate margins where continents collide, such as the Himalayas and Caucasus, also generate damaging earthquakes. This broad global classification of seismogenesis caused by convergence and divergence does not accommodate the many

University of California, Berkeley, California, U.S.A. earthquakes, including major damaging ones, that occur far from the plate boundaries, under the abyssal plains of the deep oceans [35] and within the continental crust; significant extension [34] must be made to simple plate tectonic kinematics to provide a plausible mechanical explanation for these intraplate earthquakes.

Hinterland seismic activity has been found in all continents except Greenland (see Table 1). The available earthquake catalogues that date back to the 16th century cite at least 15 major earthquakes in a crust that on the simple plate tectonic theory would be regarded as stable [27]. Going back even further, throughout the 3,000 years of historical record in China, scholars have recorded evidence of devastating earthquakes there away from the collision zone of the Himalayas and Tibet and from the subduction zones along China's eastern margin.

A striking example is the catastrophic earthquake that struck deep inside continental China in 1556 on January 23rd in Shensi Province near the old capital city of Xian. This earthquake produced the greatest loss of life ever recorded from seismic activity. The official Chinese catalogue estimates that 830,000 people died from all causes. Strong earthquakes in the European intraplate region have also been described over the historical centuries [1]. Another intraplate earthquake of exceptional size occurred in the Rann of Kutch, in northeast India in 1819. In the Kutch earthquake, a $3 \mathrm{~m}$ high scarp appeared running east to west for about $250 \mathrm{~km}$.

In North America east of the Rocky Mountains, significant earthquakes are infrequent, with a few notable exceptions [20]. The most active zone runs from southern Missouri southward along the Mississippi River. In the fall and winter of 18111812 , three principal earthquakes and numerous aftershocks occurred near the town of New Madrid, Missouri [31]. These earthquakes were of high intensity and were felt over distances 


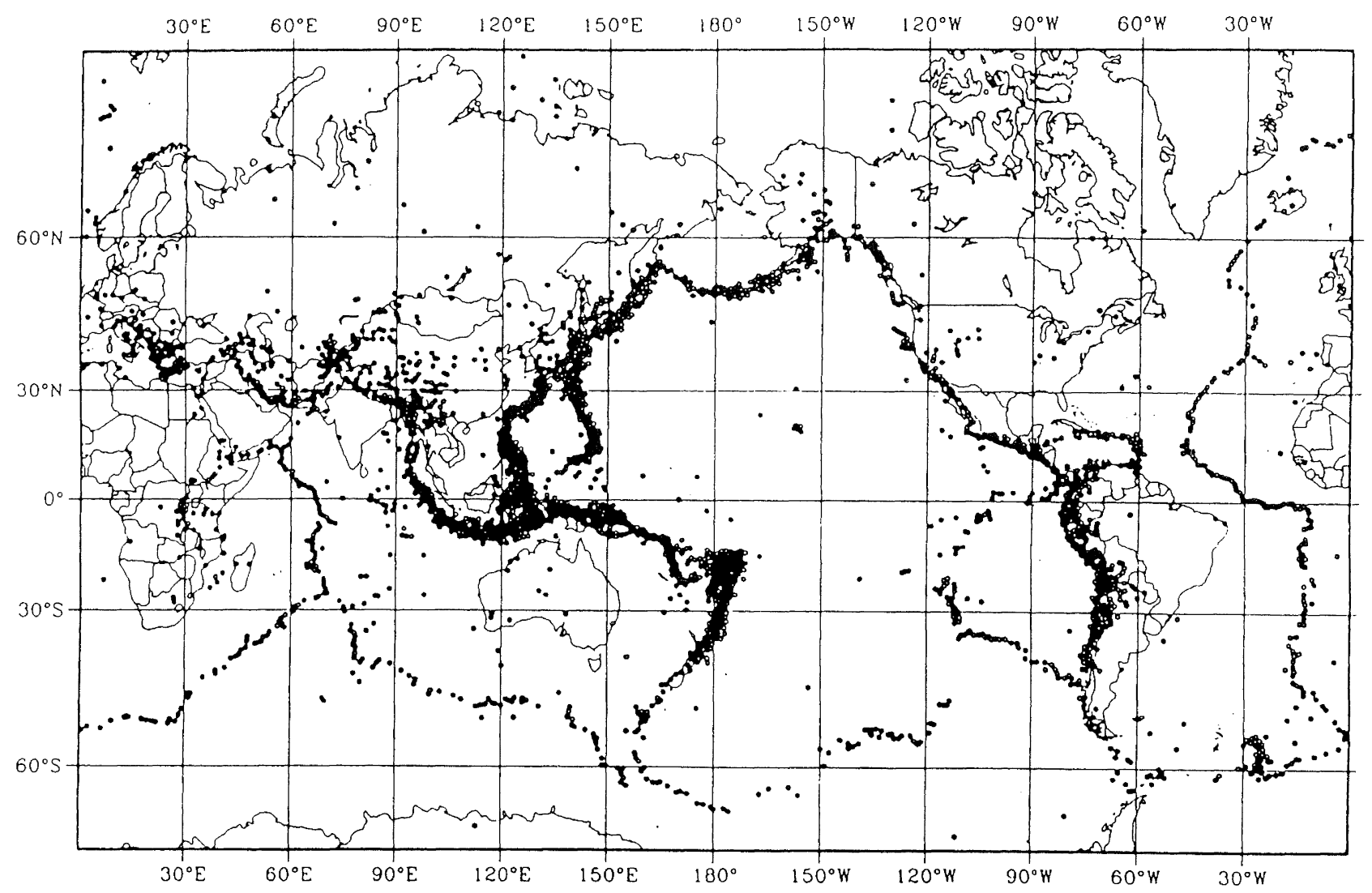

FIGURE 1 Map of global shallow seismicity, 1963-88, $M>5$, depth $<70$ kilometers. (Courtesy of National Earthquake Information Center, U.S. Geological Survey)

Table 1 Sample large intraplate earthquakes

\begin{tabular}{||l|c|c|}
\hline \multicolumn{1}{|c|}{ location } & year & $\mathrm{M}_{\mathrm{S}}$ \\
\hline \hline Basel, Switzerland & 1356 & $(7.4)$ \\
\hline Shensi, China & 1556 & $(8.0)$ \\
\hline Quebec (St. Lawrence river), Canada & 1663 & $(7.5)$ \\
\hline Shantung (Tanlu fault), China & 1668 & $(8.5)$ \\
\hline $\begin{array}{l}\text { New Madrid, U.S.A } \\
\text { (two similar earthquakes 1811,1812) }\end{array}$ & 1812 & $(8.3)$ \\
\hline Kutch, India & 1819 & $(7.8)$ \\
\hline Charleston, U.S.A. & 1886 & $(7.6)$ \\
\hline Libya, North Africa & 1935 & $(7.1)$ \\
\hline Meeberrie, Australia & 1941 & $(7.0)$ \\
\hline San Juan, Argentina & 1944 & $(6.5)$ \\
\hline Meckering, Australia & 1968 & $(6.8)$ \\
\hline Nahanni, Canada & 1985 & $(6.8)$ \\
\hline Tennant Creek, Australia & 1988 & $(6.7)$ \\
\hline Latur, India & 1993 & $(6.4)$ \\
\hline
\end{tabular}


of $1000 \mathrm{~km}$; there were reports from as far away as Washington, D.C. These intraplate earthquakes are probably the most energetic recorded in the contiguous United States, yet the closest plate boundary (the mid-Atlantic rise) is more than $4000 \mathrm{~km}$ away. Another significant seismically-active zone lies along the St. Lawrence River in the Quebec province, where large earthquakes were reported in the seventeenth century (see Table 1)

The largest historical earthquake along the eastern continental margin occurred in North Carolina in 1886, damaging Charleston. Despite extensive subsequent geological field studies, no specific surface faulting associated with any of these large earthquakes has been discovered, although the rift fault zone of the New Madrid earthquakes has now been well mapped from hypocenters of the frequent small-magnitude seismicity. Indeed, globally, in stable continental regions only 11 earthquakes are known historically to be associated with causative surface fault rupture.

\section{THE PROBLEM OF STABLE CONTINENTAL REGIONS}

As well as the historical catalogue, knowledge of earthquake occurrence depends mainly on the recent instrumental record of seismicity and on geodetic and geological studies [16]. Resulting catalogues and maps of locations and magnitudes of earthquakes down to quite small sizes provide the basis for broader statistical treatment of earthquake frequency and help define earthquake source regions. The occurrence is modelled in terms of the total number $N$ of earthquakes, magnitude $M$, during $T$ years in an area $S$ square kilometers. For a uniform distribution of sources (geological fault ignorance),

$$
\log N=a-b M+\log S+\log T,
$$

where $a$ and $b$ are observational seismicity parameters.

In seismic areas there is usually need to truncate the form (1) at a lower magnitude $M_{O}$ and a maximum credible magnitude $M_{\boldsymbol{I}}$ : $M_{O}<M<M_{1}$. These threshold values are often rather arbitrary and sometimes decisive to hazard estimation.

In order to make predictions of the probability $\mathrm{P}(\mathrm{r} \mid \mathrm{H})$ of future seismic risk $r$ with any confidence, the regressed data $\mathrm{H}$ on the limited historical seismicity should be augmented by information on the seismogenic framework provided by structural geology. The zones of high stress and current dislocation of the Earth's crust should be mapped and rates of deformation estimated by stratigraphic methods and geodetic surveys.

In stable continental areas, such as Australia [30], North America [22], the Brazilian shield, large parts of Europe [2], west Africa, and hinterland Asia, because of the long interoccurrence time of major earthquakes there are two basic difficulties in risk estimation. First, there is a general ignorance, not only of the rate of occurrence, but generally of where the main active fault sources are located. In Australia, for example, the occurrence of the damaging Newcastle earthquake of December 28, $1989(\mathrm{M}=5.6)$ was unexpected (although the region has had a few historical earthquakes); the causative fault is still a matter of speculation. By contrast, five of the ten historic earthquakes in stable continental regions that have been associated with new surface fault offsets have occurred in Australia [19], all since 1968. The rarity of such intraplate earthquake surface faulting makes their special field study especially valuable and paleoseismologic techniques have been used to determine the average interoccurrence rale of earthquakes produced by slip on such faults $[14,15,23]$

The second basic problem of seismology in areas of intraplate seismicity is constructing robust empirical models of seismic wave attenuation $[2,4]$. Generally, the attenuation of seismic waves is lower in the older stable continental shield areas than in younger crustal rocks. For example, the Modified Mercalli intensity in the eastern United States has indicated that within $100 \mathrm{~km}$ of a large earthquake the attenuation is similar to that in the west, but thereafter the distance required for the peak ground velocity to be reduced by one half, is almost double. A reliable comparison over the full frequency range of engineering interest between the wave attenuation laws for intraplate earthquakes in the eastern continental region and western interplate earthquakes is still not feasible because of the paucity of strong motion recordings from the former. Few large earthquakes necessarily mean few relevant ground motion records. Thus, from necessity, the strong motion attenuation laws used for peak motions and for spectral attenuations come from strong motion recordings in California and the western states, whereas in the eastern states, they are derived from historical intensity recordings and the few small earthquakes that have been recorded. A complication is that the seismogram wave patterns from east and west are known to differ in different frequency bands and distance ranges; for example, in the continental shield crust certain higher-mode surface waves, such as the $\operatorname{Lg}$ phase [8], propagate efficiently.

\section{ZONATION CONSIDERATIONS}

In the 1980 development of expectancy maps and the risk analysis carried out by the Applied Technology Council (ATC), the difference in seismic intensity attenuation between eastern and western United States was recognized [21]. There were two policy decisions made in the recommended nationally-applicable seismic design provisions, both of which were significant departures from past practice in zonation. The first decision was that the relation between the design lateral force and building period should take account of the distance from the anticipated earthquake sources. This objective was accomplished by using two separate ground motion parameters, namely, the effective peak acceleration and the effective peak velocity; two separate maps for the variation of these parameters were constructed. The second decision was that the probability of exceeding the assigned ground shaking should be roughly the same in all parts of the country. Until that time, zoning maps used in the United States had been based upon estimates of the maximum ground shaking experienced during the recorded historical period, with only minor consideration of how often such motions occurred.

Modern zonation procedures for intraplate earthquakes normally also represent the intensity of ground shaking by the effective values of the maximum wave scaling parameters. Supremum amplitude spikes are often erratic and not representative of the maximum sustained wave energy. The importance of other parameters, such as $S$ wave velocity and displacement pulses, has been recognized more strongly in recent studies of damage caused in the near field of such earthquakes as the 1989 Loma Prieta and 1994 Northridge earthquake [25] in California [9]. The importance of enhanced wave duration was highlighted in the 1988 Mexico earthquake that produced heavy damage in parts of Mexico City. One aspect of low attenuation of seismic waves in stable continental regions is that the surface wave trains become more prominent with distance from the causative 
fault; the $S$ wave portion and the surface wave codas lengthen because of dispersion of the wave trains with distance, particularly in large alluvial basins [5].

Zonation mapped in terms of effective peak acceleration and effective peak velocity [21] provides some statistical robustness to design regionalization maps and risk analysis. These parameters measure smoothed spectral coordinates and are related to the raw peak ground acceleration and peak ground velocities, but are not directly proportional. For ground motions of short duration, the mapped effective values are generally smaller than the peak amplitudes because the latter often appear as high frequency spikes. (It is easily demonstrated that truncation of these spikes in acceleration time histories has little effect on the response spectra computed from that motion, except at frequencies which are higher than those of interest in ordinary building practice.) The mapped effective peak velocity, however, may often be larger than the maximum measured velocity at distances of over $100 \mathrm{~km}$ from a particular major earthquake source because the ground motions increase in duration and become more periodic with distance. This larger duration tends to produce larger increases in that portion of the average response spectrum corresponding to the effective peak velocity. intensity maps which used different attenuation laws west and east of the Rocky Mountains [4]. The final ATC-3 maps had smoothed contours with less detail than the basic seismicity maps that were divided into somewhat subjective seismic source zones. (A number of sensitivity studies has shown that the weak seismogenic constraints on such selection allow a range of seismic source zones with significant consequences on the estimated seismic risk. For this reason, probabilistic algorithms that allow incorporation of such variability have particular attraction.)

More recently, a major effort in the United States was made by several groups led by the Electric Power Research Institute (EPRI) [22] and the U.S. Geological Survey (USGS) to reassess the likelihood of significant earthquakes in the eastern stable continental region of the United States. In dramatic contrast to the seismically-active western states, the only fault in the eastern region with recurrence intervals of seismic surface rupture is the Meers fault in southwest Oklahoma [17]. The fault scarp occurs in Quaternary deposits. Stratigraphic work indicated movement occurred on this fault during the past 3,000 years and perhaps as recently as 1,200 years ago. Despite such recent slip, seismographs detect no earthquakes along the fault at the present time.

In the 1980 ATC-3 study [21], construction of the design regionalization maps was facilitated by the seismic recurrence

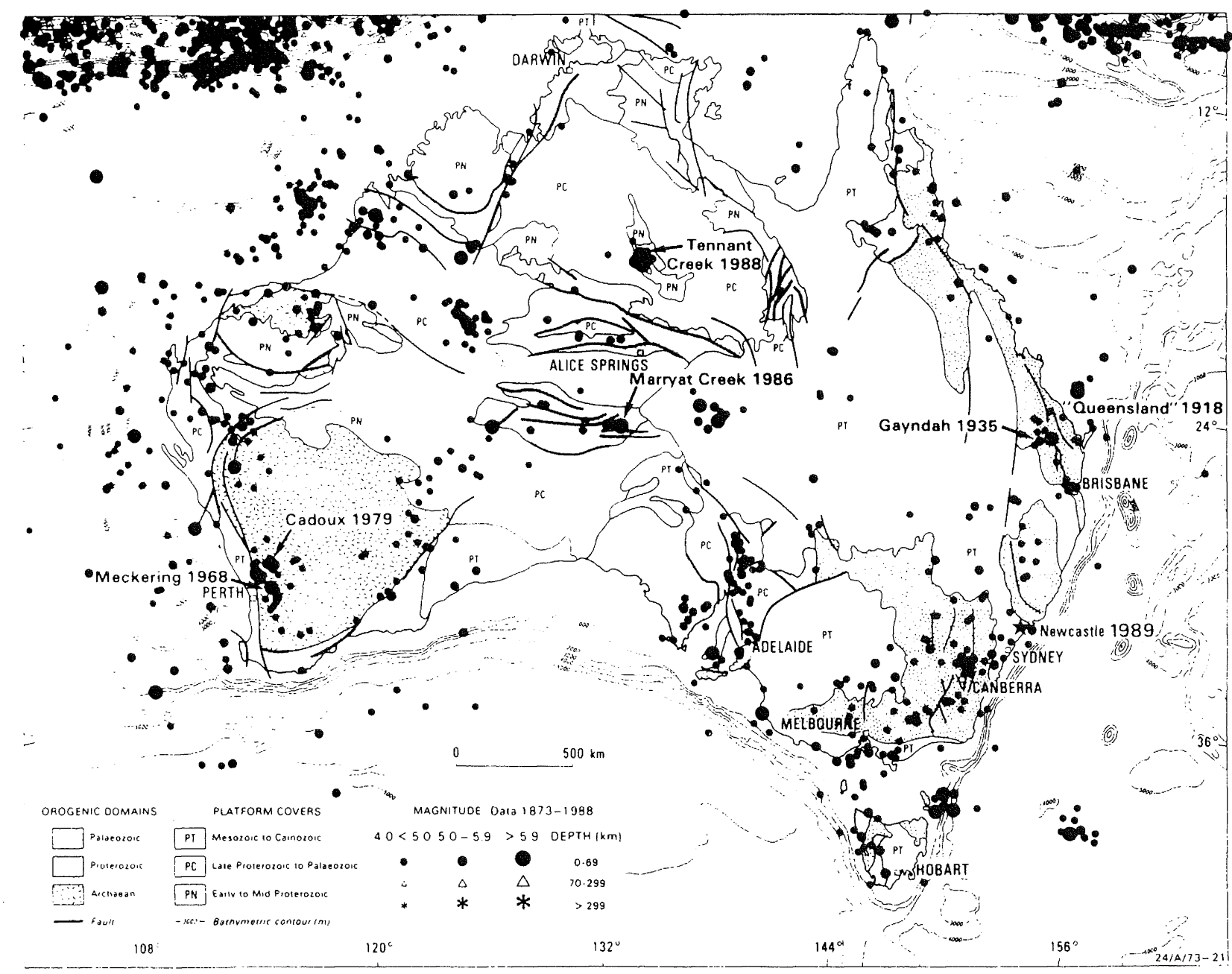

FIGURE 2 Intraplate earthquakes in Australia from 1873 to 1988 plotted on a tectonic map. (Courtesy of D. Denham, Australian Geological Survey Organization) 


\section{SURFACE FAULT RUPTURES AND INTRAPLATE EARTHQUAKES IN AUSTRALIA}

The Australian continent is a major part of the Indo-Australian plate with the nearest plate margin to this large isiand to the northwest along the subducting Java trench (Figure 2). Nevertheless, a moderate rate of intraplate activity has been recorded in historical times [19], both around the continental margin and in the interior. This seismicity entails a finite variable seismic hazard [29]. The study of the strain field and fault slip in the Australian crust is thus of global interest in relation to intraplate earthquakes.

Five surface fault ruptures have been observed and measured in earthquakes in Australia in the last three decades. These are located at Meckering (1968), Calingiri (1970), Cadoux (1979), Marryat Creek (1986) and Tennant Creek (1988). As well, a number of prehistoric fault scarps have been identified in Australia, including one near Cadell, New South Wales and Lake Edgar, Tasmania [30]. Detailed stratigraphic dating on the latter faults remains to be done.

The chevron-shaped fault scarp at Marryat Creek measured 13 $\mathrm{km}$ along the scarp trace and the thrust slip produced an earthquake of magnitude $M_{S}=5.8$. The Tennant Creek fault scarp was about $30 \mathrm{~km}$ long and had oblique-thrust dislocation. This faulting was associated with an earthquake of magnitude 6.3 followed by two additional principal earthquakes $\left(\mathrm{M}_{\mathrm{S}}=6.4\right.$ and 6.7) during the next 20 hours. The arid climate of this remote area has left the fault scarps largely unchanged in the ensuing years. Trenching and detailed stratigraphic mapping has recently produced evidence $[14,15,28]$ of historical shear zones in the bedrock at the Marryat Creek fault, but at the Tennant Creek trench sites there was no evidence for pre-existing faulting. In both cases, the recent field work has indicated recurrence intervals of large earthquakes at a scale of tens of thousands of years and even hundreds of thousands of years. Horizontal crustal compression appears to be the main tectonic force.

\section{SEISMIC HAZARD MAPPING WITHIN TECTONIC PLATES}

Procedures for constructing seismic hazard maps for risk assessment, land planning, and for engineering design criteria in building codes have evolved steadily in the last three decades. The greatest remaining uncertainties are in the assessments of specific earthquake location, and appropriate time histories and design spectra within the stable continental zones. This evolution needs quickening because the seismic danger from intraplate earthquakes continues to increase as exemplified by the Tangshan, China earthquake of July 28, 1976, which killed more than 300,000 people. One measure of this increase in seismic risk is that by the year 2000 A.D. almost half of the world's projected population will live in densely populated urban areas. A number of these areas, such as Boston, Shanghai, Melbourne, Cairo, Quebec, and many other major metropolitan centers may be shaken by intraplate earthquakes.

The most common methodology for the construction of seismic hazard maps now uses a probabilistic scheme. The method is a composite pseudo-Baysian analysis in which the evidence $\mathrm{H}$ in $\mathrm{P}(\mathrm{r} \mid \mathrm{H})$ is combined from geology, historical seismicity, plate tectonic models, and various measurements of the shaking parameters [18]. The model variability comes from the (usually subjective) assignation of odds to a finite number of plausible alternatives at each branching of a logic tree. The criticisms of the method include the non-exhaustiveness of alternatives, the non-commutation (non-independence) of probability factors, the mixing of true (observational) randomness with system uncertainty, and the lack of objective experimental tests of the probability. process assumed. Some of these difficulties are obviated by extensive sensitivity analysis, with many numerical repetitions to determine if the central tendencies are convergent. In any new application of the method, there needs to be concern of the robustness of the process and checks against observed seismicity catalogues are vital. Nevertheless, in the best zonation assessments of seismic hazard, the construction is carried out with explicit warnings about the uncertainties in the parameters of the multi-dimensional space. In practice, there is a tendency to adopt conservative results, with the consequence that structures may be over-designed.

A more fundamental seismological criticism of many risk studies is that the computational models do not encompass the complexity of strong earthquake motions [13]. Ground motion hazard or risk maps for representative sites in a continental province are usually specified in terms of seismic intensities, peak (or effective) ground accelerations, and sometimes peak velocities, and/or specific damped spectral acceleration amplitudes at a finite number of periods. (The contour parameter for the 1993 Standards Hazard Map in Australia is peak ground velocity [29].) All seismic hazard is a function of wave frequency and hazard mapping can be extended to the spacial variation of equal hazard spectra, i.e., the response spectral value which has an equal (given) likelihood of being exceeded at any (given) response period.

The above type of mapping of damage potential or vulnerability, however, excludes two key variables: duration and near-fault wave behavior. First, the duration of shaking is known to affect the capacity for elastic response of engineered structures. Collapse of 10- to 14-story buildings in the lake zone in Mexico City is a clear illustration. The 10 or more cycles of the 1985 Michoacán earthquake (centered over $350 \mathrm{~km}$ away from Mexico City), led to progressive structural weakening. In general, the shaking duration needs specification not only for acceleration but also for ground velocity and displacement, of critical importance in the case of large structures, such as long bridges, highrise buildings, and base-isolated structures [24]

Second, a difficulty with broad, smooth mapping of hazard from intraplate earthquakes is the occurrence of a large amplitude wave pulse or "fling" near to the rupturing fault. Such a phase pattern has now been measured in a number of interplate earthquakes, such as the 1971 San Fernando and 1994 Northridge earthquakes, and seismic wave theory predicts the generation of such a pulse generally for fault sources. Velocity and displacement pulses are not significantly represented in general seismic hazard mapping for continents, but may have serious consequences for building response $[6,12,25]$.

Although presenting different levels of difficulty, the selection of the maximum design intraplate earthquake for a given site should utilize the same concept of a Safety Evaluation Earthquake (SEE) as used for interplate sources. The SEE is the earthquake whose occurrence is sufficiently unlikely that it can represent the maximum earthquake to be considered in evaluating the safety of the structure. This definition not only incorporates a time frame that is realistic in relation to the type of construction involved, but also the type of structure itself. The special difficulties in assessing a deterministic or probabilistic SEE for intraplate earthquakes have been discussed 
Table 2 Algorithms for intraplate earthquake synthetics

\begin{tabular}{|c|c|c|c|}
\hline type & reference & weakness & primary product \\
\hline \hline $\begin{array}{c}\text { 1. empirical extrapolation } \\
\text { with response spectral fit }\end{array}$ & {$[24,26]$} & $\begin{array}{c}\text { lack of strong motion } \\
\text { recordings }\end{array}$ & time history \\
\hline 2. spectral attenuation & {$[4,22]$} & $\begin{array}{c}\text { poorly constrained } \\
\text { frequency to time- domain } \\
\text { transform }\end{array}$ & $\begin{array}{c}\text { uniform hazard } \\
\text { spectrum }\end{array}$ \\
\hline $\begin{array}{c}\text { 3. kinematic response - } \\
\text { function convolution }\end{array}$ & {$[11,32]$} & $\begin{array}{c}\text { uncertainty on fault } \\
\text { rupture assumptions }\end{array}$ & time history \\
\hline
\end{tabular}

in previous sections. In addition, however, even after an appropriate intraplate SEE has been defined, there remains the special difficulty in producing realistic synthetic or empirical ground motions for dynamic structural analysis [7].

With few important exceptions, because many interplate earthquakes up to magnitude 7 or so have now been recorded by accelerometers, prediction by interpolation and extrapolation from actual measured ground motions has become reliable. The exceptions are for the very largest earthquakes $(M \geq 7.5)$ and for earthquakes with normal fault sources. The lack of a similar set of ground motion measurements for intraplate earthquakes has been compensated for in a number of ways. Until shown otherwise, a basic assumption is that the same physics of earthquake genesis governs for both interplate and intraplate earthquakes. Allowance for different wave attenuation laws, crustal structures, and source mechanism $[3,7,33]$ can easily be made in computing synthetic seismograms. A variety of methods is now described in the literature $[11,12]$ : these have been applied in a number of practical cases (see Table 2 ).

Two recent case histories, using different modifications of the type 3 algorithm, deserve study: Hoover Dam (Nevada) [32] and Hudson River bridges (New York) [26]. Hoover Dam is a $221 \mathrm{~m}$ concrete gravity arch structure located near two seismogenic faults; one is a normal fault within $3 \mathrm{~km}$ of the dam and of sufficient dimension to produce a $\mathrm{M}_{\mathrm{S}}=6.5$ earthquake. A problem immediately arises that very few ground motions from normal-slip mechanism earthquakes have been recorded, even for interplate earthquakes. Therefore, the motion synthetics must be computed with little guidance from observation and no direct verification by comparisons with actual relevant accelerograms. Such computations for type 3 algorithms usually assume plausible but uncertain values for the fault area, the distribution of fault rupture velocities, slip risetimes, and other dislocation parameters [7]. The resulting synthetics must satisfy general constraints concerning the energy partition between the main seismic wave types, namely, P, S and surface waves, the relative smoothness of the ground response spectra, propagation through known local rock structures, appropriate durations, and so on.

For intraplate earthquakes where previous earthquakes are either unknown, unrecorded or small, some assistance can be attained from recordings of very small earthquakes or explosions in the same tectonic region. These sources provide time histories from which wave scattering functions and attenuation laws appropriate for the local rock conditions can be estimated. In one study of the Bronx-Whitestone bridge in New York, such scattering functions were derived and convolved with a simple source function to yield design motions, assuming that linear elastic conditions apply [26].

\section{CONCLUDING REMARKS}

The above sections have stressed that, because of the relative observational ignorance of strong motion parameters for earthquakes within the tectonic plates, both in stable oceanic [35] and continental regions, the assessment of seismic risk and seismic wave properties therein remains much more uncertain than for interplate earthquakes along plate margins, such as transform fault and subduction zones. Nevertheless, research and application developments in recent years have carried forward many key theoretical and estimation aspects of both earthquake zoning and ground motion prediction. Promising algorithms, which are mathematically powerful and physically plausible, have now been published for seismic regionalization, seismic hazard mapping, and computation of seismic wave synthetics. The appropriate probabilistic questions are now being addressed.

However, because in intraplate regions verification and validity checks on these algorithms are still necessarily limited, the conclusions, inferences, and computations based on them are critically dependent on model assumptions, uncertain selections of mathematical forms, and analogies to interplate seismicity. It is important that these assumptions not become entrenched and continued criticism and debate are needed. Above all, it is crucial that programs of seismographic instrumentation capable of recording strong ground motions not be restricted to the plate margins, but that resources be found to distribute judiciously strong motion instruments at locations that will eventually suffer intraplate earthquakes. As a start, at least one strong motion accelerometer with digital channels should be operated at every permanent seismographic observatory (such as stations of the IRIS network) in the world [10]. In this way, accelerometers at these and additional Continental Reference Stations (CRS) will inexorably provide the critical database of intraplate earthquake measurements.

\section{REFERENCES}

1 Ambraseys, N N. 1988. Engineering seismology, (First Mallet-Milne Lecture), Earthq. Engrg. and Struc. Dyn. 17: $1-105$

2 Ambraseys, N N and Bommer, J J. 1991. The attenuation of ground accelerations in Europe, Earthq. Engrg. and Struc. Dyn. 20: 1179-1202.

3 Atkinson, G M. 1993. Source spectra for earthquakes in eastern North America, Bull. Seism. Soc. Am. 83: 1778-1798. 

relations for eastern North America, Bull. Seism. Soc. Am. 85: 17-30.

Bard, P Y. 1982. Diffracted waves and displacement field over two dimensional elevated topographies, Geophys. J. Roy. Astr. Soc. 71: 731-760.

6 Bertero, V V, Mahin, S A and Herrera, R A. 1978. Aseismic design implications of near fault San Fernando earthquake records, Earthq. Engrg. and Struc. Dyn. 6: $31-42$.

7 Boatwright, J and Choy, G. 1992. Acceleration source spectra anticipated for large earthquakes in northeastern North America, Bull. Seism. Soc. Am. 82: 660-682.

Bolt B A. 1957. The velocity of the seismic waves $\mathrm{Lg}$ and $\mathrm{Rg}$ across Australia, Nature 180: 495.

9 Bolt, B A. 1971. The San Fernando Valley, California, earthquake of February 9, 1971: data on seismic hazards, Bull. Seism. Soc. Am. 61: 501-510.

Bolt, B A (Chairman). 1980. U.S. earthquake observatories: recommendations for a new national network. National Academy Press, Washington, D.C.

11 Bolt, B A (Editor). 1987. Seismic Strong Motion Synthetics. Academic Press, Orlando, Florida.

Bolt, B A. 1994. The state of the art in synthesis of strong ground motion for earthquake engineering, Proc., 10th World Conf. Earthq. Engrg., Madrid, 6487-6492.

Bolt B A. 1995. From acceleration to displacement, (Fifth Mallet-Milne Lecture), Earthq. Engrg. and Struc. Dyn. (in the press).

14 Bowman, J R and Barlow, B C. 1991. Relocation of teleseismically recorded earthquakes near Tennant Creek, Australia - implications for midplate seismogenesis, $J$. Geophys. Res. 96: 11,973-11,979.

Bowman, J R, Crone, A J and Machette, M N. 1995. The recurrence of earthquakes in the stable continental region of Australia: Marryat Creek and Tennant Creek. Electric Power Research Institute. EPRI Report TR102157. Palo Alto, California.

16 Coppersmith, K J, Johnston, J C, Kanter, L R., Youngs, R R and Metzger, A G. 1990. Methods for assessing maximum earthquakes in the eastern United States. Electric Power Research Institute. EPRI Report RP2556-12. Palo Alto, California.

17 Crone, A J and Luza, K V. 1990. Style and timing of Holocene surface faulting on the Meers fault, southwestern Oklahoma, Geol. Soc. Am. Bull. 102: 117.

18 Crone, A J, Machette, M N and Bowman, J R. 1987. Proceedings of Conference XXXIX -Directions in Paleoseismology. U.S. Geological Survey Open File Report 87-673.
Denham, D. 1988. Australian seismicity - the puzzle of the not-so-stable continent, Seism. Res. Let. 59: 235-240.

Dewey, J W, Hill, D P, Ellsworth, W L and Engdahl, E R. 1989. Earthquakes, faults and the seismotectonic framework of the contiguous United States, Geol. Soc. Am. Memoir 172: 541-575.

Donovan, N C, Bolt, B A and Whitman, R V. 1978. Development of expectancy maps and risk analysis, ASCE, J. Struc. Dyn. 104: 1179-1192.

EPRI. 1988. Engineering model of earthquake ground motion for eastern North America. Electric Power Research Institute. EPRI Report NP-6074. Palo Alto, California.

23 Fredrich, J, McCaffrey, R and Denham, D. 1988 Source parameters of seven large Australian earthquakes determined by body waveform inversion, Geophys. J. 95: $1-13$

24 Hao, H, Oliveira, C S and Penzien, J. 1989. Multiplestation ground motion processing and simulation based on SMART-1 array data, Nuclear Engrg. and Design 11: 293-310

25 Heaton, T H, Hall, J F, Wald, D J and Halling, M W 1995. Response of high-rise and base-isolated buildings to a hypothetical $\mathrm{M}_{\mathrm{W}} 7.0$ blind thrust earthquake, Science 267: 206-211.

26 Horton, S P. 1994. Simulation of strong ground motion in eastern North America, Proc., 5th National Conference on Earthq. Engrg., Earthq. Engrg. Res. Institute (EERI), Chicago, 3: 251-260.

Johnson, A C and Kanter, L R. 1990. Earthquakes in stable continental crust, Scientific American 68-75.

28 Machette, M N, Crone, A J and Bowman, J R. 1993. Geological investigations of the 1986 Marryat Creek, Australia, earthquake - implications for paleoseismicity in stable continental regions. U.S Geological Survey Bull. 2032-B.

29 Michael-Leiba, M, Jones T and McCue, K. 1993. Seismic hazard in Australia, in The practice of earthquake hazard assessment (Editor, R K McGuire). IASPEI

30 McCue, K. 1990. Australia's large earthquakes and recent fault scarps, J. Struc. Geol. 12: 761-766.

31 Nuttli, O W. 1979. The Mississippi Valley earthquakes of 1811 and 1812. Intensities, ground motion and magnitudes, Bull. Seism. Soc. Am. 63: 227-248.

32 O'Connell, D R and Ake, J P. 1995. Ground motion analysis for Hoover Dam, Boulder Canyon project. U.S Bureau of Reclamation, Seismotectonic Report 94-1.

33 Somerville, P, McLaren J, Saikia C, and Helmberger D. 1990. The 25 November 1988 Saguenay, Quebec, earthquake: source parameters and the attenuation of strong ground motion, Bull. Seism. Soc. Am. 80: 11181143. 
34 Sykes, L R. 1978. Intraplate seismicity, reactivation of preexisting zones of weakness, alkaline magmatism, and other tectonism postdating continental fragmentation, Reviews of Geophys. and Space Phys. 16: 621-688.

35 Wiens, D A and Stein, S. 1984. Intraplate seismicity and stresses in young oceanic lithosphere, J. Geophys. Res. 89: 11,442-11,464 